\title{
ANALISIS NILAI TAMBAH PETERNAK DAN PEJAGAL ATAS BIAYA YANG DICIPTAKAN PADA PEMASARAN SAPI POTONG DI KECAMATAN LOLONG GUBA
}

\author{
Adolf B. Heatubun ${ }^{1 *}$, Marcus Veerman ${ }^{2}$, Michel J. Matatula ${ }^{2}$ \\ ${ }^{1)}$ Universitas Kristen Indonesia \\ Jl. Mayjen Sutoyo, Jakarta Timur, DKI Jakarta 13630 \\ ${ }^{2)}$ Jurusan Peternakan, Fakultas Pertanian, Universitas Pattimura \\ Jl. Ir.M. Putuhena, Kampus Poka, Ambon 97233 \\ * Email: adolf.heatubun@uki.ac.id
}

\begin{abstract}
ABSTRAK
Konsep nilai tambah dalam bidang pertanian memiliki peran penting dalam pengembangan, baik produksi, konsumsi, maupun perdagangan. Produsen, konsumen, dan pelaku pasar memanfaatkan konsep tersebut untuk menciptakan produktivitas di lingkungan masing-masing. Penelitian ini bertujuan menganalisis nilai tambah produk yang diciptakan oleh peternak sapi potong dan pejagal/pemotong sapi di Kecamatan Lolong Guba, Kabupaten Buru. Penelitian menggunakan metode survey, sampel dipilih secara purposive sampling untuk kecamatan, peternak, dan pejagal. Penelitian berlangsung bulan April hingga Mei 2020. Analisis menggunakan teknik identifikasi, pengukuran dan rasio. Hasil penelitian menunjukkan kegiatan bernilai tambah peternak mencakup menggembalakan ternak dan menggemukan sapi. Untuk pejagal mencakup membeli dan memotong sapi serta menjual daging. Biaya peternak mencakup pemberian hijauan, pemeliharaan dan penggembalaan ternak. Biaya pejagal mencakup pembelian sapi, transportasi, retribusi dan pemotongan $(\mathrm{RPH})$. Nilai tambah peternak sapi lebih tinggi dan meningkat dibanding pejagal. Produktivitas menciptakan nilai tambah dari peternak sapi lebih tinggi dibanding pejagal. Peternak lebih unggul dalam pemeliharaan ternak, sedangkan pejagal lebih unggul dalam frekuensi waktu pemotongan.
\end{abstract}

Kata kunci: Identifikasi, kegiatan bernilai tambah, reward, value added, ternak sapi

\section{ANALYSIS OF VALUE ADDED OF FARMER AND SLAUGTERERS ABOVE THE COST CREATED IN THE MARKETING OF BEEF CATTLE IN LOLONG GUBA DISTRICT}

\begin{abstract}
The concept of added value in agriculture has an important role in development, both production, consumption and trade. Producers, consumers, and market players take advantage of this concept to create productivity in their respective environments. This study aims to analyze the added value of the products created by beef cattle breeders and cattle slaughterers in Lolong Guba District, Buru Regency. The study used a survey method, the sample was selected by purposive sampling for the districts, breeders and slaughterers. The study was conducted from April to May 2020. The analysis used identification, measurement and ratio techniques. The results showed that value-added activities of breeders included herding and fattening cattles. For the slaughterers includes buying and slaughtering cattles and selling meat. The cost of the breeders includes providing forage, caring for and grazing the livestock. The cost of slaughtering includes the purchase, transportation, retribution and slaughter of cattles at arbatoir. The added value at cattle breeders is higher in comparison to slaughterers. Productivity creates added value at cattle breeders higher than slaughterers. Breeders are superior in raising livestock, while slaughterers are superior in frequency of slaughtering time.
\end{abstract}

Key words: Identification, value added activities, reward, value added, cattle

\section{PENDAHULUAN}

Setiap pelaku ekonomi dalam berbagai kegiatan baik level produksi maupun pemasaran output mengharapkan nilai balas jasa yang layak dari seluruh pengorbanan yang telah dicurahkan pada kegiatan usahanya. Balas jasa memiliki arti sebagai penghargaan yang diberikan kepada para pekerja yang telah memberikan jerih payahnya dalam bekerja dan menciptakan produksi (Satka, 2019). Balas jasa atau 
reward ini sendiri dianggap sebagai faktor kunci untuk meningkatkan kinerja pekerja sehingga tercipta produktivitas yang tinggi (Qureshi et al., 2010). Umumnya dari sudut pandang organisasi atau perusahaan, indikator yang dipakai sebagai petunjuk balas jasa adalah laba atau keuntungan usaha. Namun dalam arah menciptakan produktivitas secara luas, tidak cukup hanya besaran laba yang dijadikan ukuran, melainkan laba harus diperbandingkan dengan biaya yang dikeluarkan. Makin tinggi nilai atau angka perbandingan tersebut, makin besar balas jasa yang diterima pelaku ekonomi.

Laba atau profit diartikan sebagai selisih antara total penerimaan dan total biaya (Salvatore, 2005 ; Aschea et al., 2007 ; Prasetyo et al., 2012). Dalam menilai ukuran laba, tidak saja digunakan pengukuran akuntansi tetapi dapat dianalisis sebagai indikator dinamis untuk mengukur berbagai efek dan dampak ke depan. Puspitaningtyas et al. (2018) menyatakan laba berfungsi sebagai indikator yang menunjukkan perusahaan berhasil atau tidak dalam aktivitasnya. Artinya, besaran laba akan mewakili realitas perubahan ekonomi perusahaan. Karena itu laba dipakai sebagai alat yang mencerminkan upaya perusahaan meningkatkan kemampuan ekonomi dan manfaat yang dapat disumbangkan bagi masyarakat luas. Dalam hal ini laba dijadikan instrumen informasi ekonomi yang memberikan value added bagi penggunanya. Pengertian nilai tambah ekonomis didefinisikan sebagai selisih antara keuntungan dari operasi bersih perusahaan dan biaya modal membangun usaha (Al-Awawdeh \& AlSakini, 2018). Juga Hall (2013), menyatakan bahwa nilai tambah ekonomi mengukur nilai uang dari pengembalian perusahaan melebihi biaya peluangnya. Ini menunjukkan bahwa nilai tambah merupakan nilai yang layak diterima perusahaan di atas biaya yang dikeluarkan.

Di bidang pertanian, nilai tambah (value added) diartikan sebagai perubahan dalam keadaan fisik atau bentuk produksi dengan menerapkan metode produksi atau proses penanganan untuk meningkatkan nilai produk akhir yang berguna dan dihargai oleh konsumen (Amanor-Boadu, 2003). Sesuai definisi ini maka perlu diberikan penghargaan kepada para pelaku yang melakukan kegiatan untuk meningkatkan nilai tambah tersebut. Imbalan atau penghargaan kepada aktivitas yang memberikan nilai tambah diantaranya dapat berupa harga yang lebih tinggi.

Pemeliharaan dan pemasaran sapi potong di Kecamatan Lolong Guba Kabupaten Buru melibatkan para peternak sapi di lokasi desa dan para pejagal/pemotong hewan sapi untuk dijual ke pasar di kota kecamatan. Aktivitas peternak sapi pada dasarnya adalah memelihara dan menggemukkan sapi untuk tujuan dijual. Sedangkan pejagal melakukan aktivitas membeli sapi di lokasi peternak kemudian membawanya ke kota kecamatan untuk dipotong dan dijual ke konsumen.

Tipe kegiatan ini baik di tingkat peternak maupun di tingkat pejagal, keduanya menciptakan nilai tambah bagi produk yang ditangani. Peternak dalam keseharian kegiatannya tidak menyadari bahwa kegiatan yang dilakukannya sesungguhnya telah membuat penambahan nilai bagi produknya sehingga dapat dikonsumsi konsumen dengan lebih baik di kemudian hari. Begitu juga pejagal, meskipun untuk tujuan memperoleh keuntungan, namun tidak disadari telah menciptakan nilai tambah yang dapat disumbangkan kepada konsumen akhir. Bagaimana kedua pelaku menciptakan nilai tambah bagi produk sapi potong dan daging, dan siapa pelaku yang menciptakan nilai tambah yang lebih besar, dapat dianalisisi dalam penelitian ini.

Penelitian ini bertujuan menganalisis nilai tambah yang diciptakan atas produk di tingkat peternak sapi potong dan di tingkat pejagal/pemotong sapi pada kecamatan. Analisis ini bermanfaat untuk melihat seberapa besar distribusi nilai tambah untuk masingmasing pelaku, dan memberikan informasi umum tentang keadaan pemasaran sapi potong di Kecamatan Lolong Guba Kabupaten Buru Provinsi Maluku.

\section{BAHAN DAN METODE}

Penelitian ini menggunakan metode survey dengan mengambil sampel peternak sapi potong dan pejagal/pemotong sapi di Kecamatan Lolong Guba Kabupaten Buru. Penelitian berlangsung dari bulan April hingga Mei 2020. Kabupaten Buru memiliki 10 kecamatan sehingga pengambilan satu kecamatan (Lolong Guba) sebagai sampel merupakan $10 \%$ keterwakilan dari kecamatan yang ada. Pemilihan Kecamatan Lolong Guba dilakukan secara purposive sampling, yakni Kecamatan Lolong Guba merupakan kecamatan dengan populasi sapi terbanyak kedua (3.847 ekor) setelah Kecamatan Waelata (5.471 ekor). Juga Kecamatan Lolong Guba merupakan kecamatan dengan pemotongan sapi terbanyak ketiga yaitu sebesar 365 ekor pada tahun 2018 (BPS Kabupaten Buru, 2019).

Peternak sapi potong yang diambil sebagai sampel dalam penelitian ini sebanyak 10 peternak dan diambil dengan metode purposive sampling. Artinya peternak yang dipilih adalah peternak yang sering menjual ternaknya dalam waktu sekarang. Umumnya peternak yang menjual sapi potong adalah peternak yang memiliki ternak berumur kurang lebih tiga tahun dan siap untuk dijual. Karena penelitian ini ingin mengetahui keadaan pemasaran sapi potong maka pemilihan sampel peternak yang benar-benar menjual ternaknya merupakan penentuan yang tepat sasaran.

Kecamatan Lolong Guba memiliki 10 desa dan 24 dusun, dan tidak tersedia data jumlah peternak 
Agrinimal, Vol. 8, No. 2, Oktober 2020, Hal. 65-

keseluruhan. Di sisi lain perilaku dan informasi tentang penjualan sapi potong yang dilakukan para peternak di kecamatan ini umumnya homogen. Karena itu pengambilan peternak sampel dalam jumlah kecil pun (10 peternak) sudah cukup untuk mewakili seluruh populasi peternak di kecamatan ini.

Pengambilan sampel pejagal/pemotong sapi sebanyak dua orang. Penentuan sampel pejagal dilakukan secara purposive sampling, yakni pejagal adalah pelaku pembeli sapi langsung ke tempat peternak sapi di lokasi desa-desa di Kecamatan Lolong Guba. Informasi bahwa kedua pejagal sampel adalah pelaku pemotong sapi potong dan pembeli langsung ke lokasi peternak, diperoleh dari dari tenaga PPL setempat. Umumnya kedua Pejagal ini secara rutin melakukan pembelian dan pemotongan sapi di Kecamatan Lolong Guba dan menjual daging sapi dan hasil ikutannya di pasar kecamatan bersangkutan. Kondisi yang dihadapi kedua pejagal secara umum sama, baik informasi harga beli sapi hidup maupun harga jual daging di pasar setempat.

Sesuai kondisi pembelian sapi potong dan penjualan daging sapi hanya di pasar kecamatan setempat (Lolong Guba) maka analisis dalam penelitian ini diarahkan pada value added (nilai tambah) yang diciptakan baik untuk peternak maupun pejagal berdasarkan struktur biaya masing-masing. Analisis juga dikembangkan untuk menge-tahui proporsi nilai tambah di atas komponen biaya yang terjadi.

Data yang dikumpulkan dan dianalisis adalah data primer yang diperoleh melalui hasil wawancara dari kedua kelompok sampel dengan menggunakan alat bantu kuesioner. Metode analisis yang digunakan adalah teknik identifikasi dan pengukuran biaya, kegiatan bernilai tambah dan nilai tambah, analisis rasio dan analisis perban-dingan. Teknik identifikasi dan pengukuran adalah cara mendefinisikan kegiatan bernilai tambah, biaya yang dibangun, dan nilai tambah yang tercipta. Penilaian masing-masing komponen sesuai dengan keadaan setempat. Variabel yang diukur mencakup :

\begin{tabular}{|c|c|}
\hline $\mathrm{CPtr}$ & 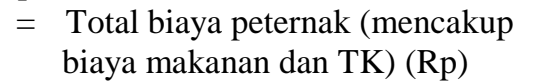 \\
\hline CPj1 & $\begin{aligned}= & \text { Total biaya pejagal (mencakup } \\
& \text { biaya pembelian sapi, transportasi, } \\
& \text { retribusi dan RPH) }(\mathrm{Rp})\end{aligned}$ \\
\hline Rwrd & $\begin{aligned}= & \text { Nilai penghargaan }(\text { reward }) \text { terha- } \\
& \text { dap kegiatan benilai tambah } \\
& \text { peternak maupun pejagal }(\mathrm{Rp})\end{aligned}$ \\
\hline VA & $\begin{array}{r}\text { Value added (nilai tambah) yang } \\
\text { diterima peternak dan pejagal di } \\
\text { atas biaya pengorbanannya }(\mathrm{Rp})\end{array}$ \\
\hline VA\% & $\begin{aligned}= & \text { Value added (nilai tambah) } \\
& \text { peternak dan pejagal dalam persen } \\
& \text { di atas reward yang diterima oleh } \\
& \text { masing-masing pelaku (\%) }\end{aligned}$ \\
\hline
\end{tabular}

\author{
$\mathrm{VA} / \mathrm{C}=$ Rasio value added peternak dan \\ pejagal di atas biaya kegiatan \\ bernilai tambah masing-masing \\ pelaku (\%).
}

\section{HASIL DAN PEMBAHASAN}

\section{Karakteristik Peternak Sapi dan Pejagal}

Peternak sapi potong di Kecamatan Lolong Guba umumnya memelihara sapi dalam skala kecil dan menjadikan ternak sapi sebagai tabungan di mana sewaktu-waktu dapat dijual untuk memenuhi kebutuhan keluarga. Ukuran pemeliharaan yang kecil menyebabkan saat menjual sapi biasanya peternak hanya menjual sebanyak satu ekor, dan atau dapat menjual sapi sebanyak dua kali dalam setahun. Kalaupun ada peternak yang menjual sapi lebih dari dua kali setahun (atau lebih dari 2 ekor) hanyalah sebagian kecil dari peternak yang relatif memiliki jumlah sapi lebih banyak dibanding peternak lainnya.

Peternak biasanya menjual sapi dalam bentuk hidup (ekor) di mana didatangi oleh pembeli (pejagal) dari kota kecamatan. Penjualan sapi di lokasi peternak lebih memudahkan peternak dan tidak memerlukan biaya. Peternak hanya menunggu jika para pejagal datang untuk membeli.

Peternak memelihara sapi dengan penggunaan input yang relatif murah. Rumput makanan ternak diperoleh dari lokasi peternak sendiri tanpa dibeli sedangkan tenaga kerja berasal dari dalam keluarga. Karena itu penilaian atas biaya pemeliharaan sapi dilakukan dengan mengestimasi nilai-nilai input tersebut sesuai keadaan setempat.

Di lain pihak pembeli sapi (pejagal) adalah para pelaku usaha individu pemotongan sapi di kota kecamatan yang kegiatannya adalah membeli sapi langsung ke lokasi peternak, kemudian membawa ke kota kecamatan dan memotong sendiri sapi pembeliannya dan menjualnya ke konsumen akhir.

Kegiatan pembelian sapi ke peternak oleh pejagal umumnya dilakukan setiap minggu, dan sesuai dengan keadaan permintaan daging sapi di pasar kecamatan. Dalam keadaan permintaan konsumen yang meningkat, pejagal dapat saja membeli sapi ke peternak dengan frekuensi yang lebih cepat.

\section{Perincian Biaya Peternak Sapi Potong dan Pejagal}

Biaya produksi merupakan salah satu komponen utama dalam menilai keberhasilan suatu operasi usaha. Biaya memiliki arti penting sebagai pembangun atau penggerak usaha. Dari awal, sebuah usaha didirikan dengan menggunakan berbagai komponen bahan dan alat bangunan sebagai pembentuk usaha tersebut. Komponen bahan dan alat yang diperlukan pada dasarnya membutuhkan biaya untuk pengadaannya, 
bahkan dalam unit usaha tertentu selain bahan dan alat, juga diperlukan uang tunai sebagai modal utama.

Ketika mengukur keberhasilan sebuah usaha dari sisi penciptaan nilai tambah (value added) maka penilaian yang dilakukan perlu berlandaskan pada kegiatan apa yang mencerminkan penciptaan nilai tambah tersebut terjadi dan bukan pada kegiatan usaha secara keseluruhan (semua aspek). Hal ini disebabkan karena tidak semua kegiatan dalam usaha yang memiliki konsekuensi biaya, tidak langsung diarahkan untuk menciptakan nilai tambah bagi sebuah produk. Dengan demikian dalam mengidentifikasi biaya dalam usaha peternakan sapi potong untuk tujuan penciptaan nilai tambah, hanya diarahkan pada kegiatan yang benarbenar untuk menciptakan peningkatan nilai bagi produk yang dihasilkan. Hal ini sesuai dengan Amanor-Boadu (2003) yang menyatakan bahwa kegiatan yang dievaluasi untuk peningkatan nilai tambah adalah kegiatan yang berkontribusi memberikan nilai tersebut.
Juga, biaya yang dihitung disini adalah biaya dari sumberdaya yang digunakan dalam produksi produk tersebut.

Berdasarkan konsep nilai tambah, estimasi biaya untuk peternak sapi potong di Kecamatan Lolong Guba Kabupaten Buru dapat dilihat pada Tabel 1. Peternak sapi dalam tujuan ingin memasarkan ternaknya bila sudah dewasa (sekitar 2,5 - 3 tahun), memulai pemeliharaan dengan asumsi mereka telah memiliki bibit (anak sapi) yang berasal dari pemeliharaan induk yang telah ada sebelumnya. Karena itu anak sapi yang saat ini dipelihara untuk tujuan dipasarkan diawali dengan pemeliharaan dan pemberian makanan ternak (hijauan). Pemeliharaan terkait dengan penggembalaan dan penanganan ternak secara baik sehingga memungkinkan ternak bertumbuh dan bertambah bobot badannya. Hal ini terkait dengan penggunaan tenaga kerja di mana peternak sendiri sebagai tenaga kerja keluarga.

Tabel 1. Perincian Biaya Pemeliharaan Peternak untuk Satu Ekor Sapi

\begin{tabular}{lccccc}
\hline \multirow{2}{*}{ Tahun } & $\begin{array}{c}\text { Umur Sapi } \\
\text { (tahun) }\end{array}$ & \multicolumn{2}{c}{$\begin{array}{c}\text { Estimasi Biaya per Hari } \\
(\mathrm{Rp})\end{array}$} & $\begin{array}{c}\text { Total Biaya per } \\
\text { Tahun (Rp) }\end{array}$ \\
\cline { 3 - 5 } & & Makanan & Tenaga Kerja & Jumlah & \\
\hline Pertama & 1 & 1.000 & 2.000 & 3.000 & 1.080 .000 \\
Kedua & 2 & 2.000 & 2.000 & 4.000 & 1.440 .000 \\
Ketiga & 3 & 3.000 & 2.000 & 5.000 & 1.800 .000 \\
\hline
\end{tabular}

Sumber : data lapangan, diolah.

Pemberian makanan untuk ternak sapi di lokasi peternak umumnya tersedia secara alami dan bebas dikonsumsi ternak berupa hijauan yang tidak dibeli atau tidak memerlukan biaya untuk pengadaannya. Meskipun tidak mengeluarkan biaya, baik untuk tenaga kerja keluarga (peternak) maupun biaya hijauan, secara ekonomi perhitungan biaya secara implisit perlu dilakukan sehingga nilai yang diterima sebagai hasil akhir bermakna ekonomis.

Pengukuran biaya implisit pada peternak sapi mencakup makanan/hijauan dan tenaga kerja peternak. Pada saat ternak sapi berumur hingga satu tahun, estimasi biaya makanan dipatok sebesar Rp. 1.000,- per hari dan biaya tenaga kerja diestimasi sebesar Rp. 2.000,- per hari. Baik estimasi biaya makanan maupun tenaga kerja per hari diakumulasi sebagai nilai kesatuan dari kegiatan peternak pada pagi hari mengantar sapi ke padang dan mengikatnya, dan pada sore hari peternak mengantar kembali ke lokasi rumahnya. Waktu selain mengantar ke padang dan mengembalikan ternak digunakan peternak untuk bekerja di kebun. Karena itu estimasi biaya untuk aktivitas peternak ini dinilai relevan sebesar Rp. 3.000,- per hari.

Ketika sapi berumur hingga dua tahun, estimasi biaya berubah di mana biaya makanan meningkat menjadi Rp. 2.000,-- sedangkan biaya tenaga kerja tetap. Peningkatan biaya makanan disesuaikan dengan kondisi pertumbuhan sapi yang makin besar dan berat badan yang meningkat yang mana konsumsi hijauan makin bertambah. Total biaya melayani ternak naik menjadi Rp. 4.000,-, begitu juga ketika umur sapi bertambah dari 2 menjadi 3 tahun di mana tiba waktunya sapi akan dijual. Estimasi biaya makanan naik menjadi Rp. 3.000,- dan biaya tenaga kerja tetap, sehingga total biaya melayani ternak per hari mencapai Rp. 5.000.-.

Estimasi biaya peternak di atas cukup rendah sesuai kondisi peternak dan dianggap relevan mewakili pengeluaran biaya bagi peternak sapi di Kecamatan Lolong Guba Kabupaten Buru. Bila dihitung pengeluaran biaya selama 3 tahun pemeliharaan sapi maka hasilnya seperti tertera pada Tabel 1 di atas.

Estimasi biaya khusus bagi pejagal/ pemotong sapi di Kecamatan Lolong Guba dilakukan mengikuti kondisi riil di lapangan. Pejagal/pemotong sapi melakukan pembelian dan pemotongan sapi secara periodik pada setiap minggu. Jumlah sapi yang dibeli dan dipotong untuk dijual sebanyak satu ekor per minggu dan operasi ini berulang setiap minggu selama setahun. Biaya yang dikeluarkan pejagal untuk membuat nilai tambah bagi konsumen di pasar 
Kecamatan Lolong Guba mulai dari membeli sapi hingga ke pasar daging mencakup tipe biaya-biaya antara lain membeli sapi dari peternak, transportasi, membayar retribusi bagi pemerintah setempat, dan biaya pemotongan (RPH). Besaran komponen biaya tersebut dapat dilihat pada Tabel 2.

Tabel 2. Perincian Biaya Pembelian dan Pemotongan Sapi oleh Pejagal untuk Satu Ekor Sapi

\begin{tabular}{lccccc}
\hline \multirow{2}{*}{ Periode } & $\begin{array}{c}\text { Sapi } \\
\text { (ekor) }\end{array}$ & \multicolumn{3}{c}{$\begin{array}{c}\text { Biaya Pembelian dan Pemotongan } \\
\text { (Ribu Rp) }\end{array}$} & $\begin{array}{c}\text { Total Biaya } \\
\text { (Ribu Rp) }\end{array}$ \\
\cline { 3 - 5 } & & Sapi & Transportasi & Retribusi danRPH & \\
\hline 1 Minggu & 1 & 5.145 & 100 & 60 & 5.305 \\
1 Bulan & 4 & 20.580 & 400 & 240 & 21.220 \\
1 Tahun & 52 & 267.540 & 5.200 & 3.120 & 275.860 \\
\hline
\end{tabular}

Sumber : data lapangan, diolah.

Sesuai data di atas, proporsi komponen biaya yang paling besar dalam menciptakan nilai tambah bagi daging sapi adalah biaya pembelian sapi dari peternak. Sedangkan komponen biaya lainnya sangat kecil. Karena itu hal ini mempermudah pejagal dalam menaksir besaran keuntungan yang dapat diperolehnya dalam satu kali kegiatan pembelian dan pemotongan sapi.

Jika kegiatan ini dilakukan pejagal sepanjang tahun maka membutuhkan biaya yang cukup besar namun dapat juga dengan tepat dihitung besaran keuntungan yang diperoleh. Tentu saja besaran penghargaan yang layak diberikan kepada pejagal akan memberikan motivasi untuk melakukan kegiatannya secara rutin. Widarti et al. (2018) menyatakan bahwa laba yang dilaporkan akan memberikan motivasi manajerial bagi pelaku usaha untuk meningkatkan laba di masa depan.

\section{Kegiatan Bernilai Tambah untuk Peternak Sapi dan Pejagal / Pemotong Sapi}

Sebagaimana dijelaskan sebelumnya bahwa tidak semua kegiatan dalam suatu operasi usaha dapat menciptakan pertambahan nilai bagi suatu produk.
Terdapat kegiatan tertentu yang dikhususkan untuk menciptakan tambahan nilai bagi sebuah produk. Dalam kegiatan pemeliharaan ternak sapi oleh peternak, peternak tidak tahu atau belum menyadari bahwa kegiatannya untuk melayani sapi makan dan minum setiap hari, dan merawat agar ternaknya tumbuh dengan baik, tidak sakit, dan bertambah bobot badannya adalah kegiatan yang menciptakan nilai tambah untuk produknya (sapi). Kegiatan bernilai tambah yang dilakukan peternak dan besaran estimasi biayanya dapat dilihat pada Tabel 3. Sedangkan biaya secara rinci dapat dilihat pada Tabel 1 di atas.

Sebagaimana contoh yang dikemukakan oleh Amanor-Boadu (2003) yang menjelaskan konsep "nilai tambah" untuk aplikasi di bidang pertanian, bahwa seorang produsen sapi yang menjadi pemasok utama ke pabrik pemotongan memutuskan untuk menyortir sapi pengirimannya agar deviasi standar bobot badan dan ukuran setiap kelompok sapi diminimalkan. Dengan penyortiran ini maka akan meningkatkan efisiensi pemotongan di pabrik, dan prosesor bersedia memberikan penghargaan sebesar tambahan $\$ 1$ per ekor kepada produsen sapi. Jika biaya penyortiran per ekor sebesar \$ 0,5 maka profit produsen sapi telah meningkat \$ 0,5 per ekor.

Tabel 3. Identifikasi Kegiatan Niai Tambah Peternak Sapi di Kecamatan Lolong Guba, Kabupaten Buru

\begin{tabular}{lclc}
\hline \multicolumn{1}{c}{ Tahun } & Umur Sapi (th) & \multicolumn{1}{c}{$\begin{array}{c}\text { Kegiatan } \\
\text { Bernilai Tambah }\end{array}$} & $\begin{array}{c}\text { Biaya (Cptr) } \\
(\mathrm{Rp})\end{array}$ \\
\hline Pertama & 1 & Menggembalakan ternak & 1.080 .000 \\
Kedua & 2 & Menggembalakan ternak & 1.440 .000 \\
Ketiga & 3 & Menggembalakan dan Menggemukan sapi & 1.800 .000 \\
\hline
\end{tabular}

Sumber : data lapangan, diolah.

Kegiatan bernilai tambah yang telah dilakukan peternak dengan memelihara dan memberi makan sapi setiap hari telah memberikan nilai yang meningkat bagi sapi jika nanti sapi dijual pada umur 1 tahun, 2 tahun, dan atau 3 tahun. Kegiatan menciptakan nilai tambah pada ternak saat sapi berumur 1 tahun dan 2 tahun adalah hanya memelihara dan memberi makanan, tetapi pada tahun ke-3 kegiatan bernilai tambah diperluas dengan kegiatan penggemukan. Kegiatan penggemukan menjadi fokus peternak di tahun ketiga karena sudah mendekati waktu penjualan sapi. 
Kegiatan menciptakan nilai tambah pada pejagal/pemotong sapi mencakup membeli sapi dari petani di desa, membawanya ke kota kecamatan, memotong sapi dan kemudian menjualnya dalam bentuk kilogram daging, tulang, dan jeroan. Identifikasi kegiatan bernilai tambah bagi pejagal dapat dilihat pada Tabel 4.

Kegiatan membeli sapi dari peternak dan memindahkannya ke lokasi kota kecamatan adalah sebuah kegiatan distribusi yang mengubah nilai tambah ternak sapi di tingkat petani menuju nilai tambah yang baru di tingkat kota kecamatan. Begitu juga kegiatan pejagal memotong ternak sapi yang dibeli (ekor) dan menjual dalam bentuk kilogram daging adalah kegiatan menciptakan nilai tambah yaitu mengubah bentuk produk dari per ekor sapi menjadi per kilogram yang dapat dibeli oleh konsumen sesuai kebutuhannya. Kegiatan ini memiliki muatan penggunaan teknologi sehingga produk memiliki nilai yang meningkat dari ekor sapi menjadi bagian-bagian daging, tulang dan jeroan yang dapat dikonsumsi secara terpisah. Dengan demikian kegiatan yang menggunakan teknologi pemrosesan (processing technology) ini layak dihargai atau mendapat reward yang sesuai.

Tabel 4. Identifikasi Kegiatan Niai Tambah Pejagal Sapi di Kecamatan Lolong Guba, Kabupaten Buru

\begin{tabular}{lclr}
\hline \multicolumn{1}{c}{ Periode } & Sapi (ekor) & \multicolumn{1}{c}{ Kegiatan Bernilai Tambah } & Biaya (Cpjl) (Rp) \\
\hline 1 Minggu & 1 & Membeli sapi/menjual daging & 5.340 .000 \\
1 Bulan & 4 & Membeli sapi/menjual daging & 21.360 .000 \\
1 Tahun & 52 & Membeli sapi/menjual daging & 277.680 .000 \\
\hline
\end{tabular}

Sumber: data lapangan, diolah.

Identifikasi kegiatan bernilai tambah yang diciptakan pejagal ini sejalan dengan Lu \& Dudensing (2015) yang menyatakan bahwa faktor seperti lokasi produksi dan teknologi merupakan komponen penting yang dapat memberikan peluang bagi terciptanya nilai tambah produk. Misalnya, jika produk yang semula berada pada lokasi tertentu dan memiiki nilai rendah, sekarang telah berpindah ke lokasi yang baru dan memberikan nilai yang lebih tinggi, akan dihargai oleh pengguna dengan nilai yang layak. Juga dengan teknologi prosesing telah mengubah seekor sapi menjadi bagian-bagian daging, tulang dan jeroan, menyumbangkan nilai tambah bagi produk. Semua kegiatan ini menyediakan kenyamanan dalam konsumsi kepada konsumen.

\section{Reward, Value Added dan Perbandingan Value Added di atas Biaya Kegiatan Bernilai Tambah Peternak Sapi dan Pejagal / Pemotong Sapi}

Adalah hal yang unik bagi peternak yaitu memelihara sapi hingga berumur tiga tahun baru menjualnya secara cash. Pada umumnya orang menilai bahwa sapi yang dipelihara peternak baru memperoleh nilai setelah dijual (sapi berumur sekitar 3 tahun). Selama masih dalam tahap pemeliharaan yaitu umur sapi dari 1 hingga 2 tahun atau lebih, ternak sapi hanya dinilai atau diperhitungkan sebagai tabungan (nilai implisit). Bilamana sapi sudah berumur 3 tahun dan dijual, barulah nilai yang benar-benar riil dan dianggap berharga adalah harga yang dikenakan pada sapi tersebut, dan nilai perhitungan sapi sebagai tabungan diabaikan begitu saja. Hal ini tidak memiliki landasan yang kuat dalam mengukur dan memberikan penghargaan yang layak bagi peternak. Bilamana pada saat menjual ternak sapi yang telah dipelihara selama 3 tahun dan harganya kebetulan rendah karena suatu sebab, maka mungkin dianggap bahwa peternak tetap memperoleh keuntungan dari harga penjualan tersebut. Hal ini dapat menyesatkan karena mungkin saja peternak memperoleh kerugian dari harga jual yang rendah. Padahal peternak telah memberikan pengorbanan selama 3 tahun untuk ternaknya dan memiliki nilai tambah yang tidak diperhitungkan. Di sisi lain peternak telah melakukan kegiatan penciptaan nilai tambah dan telah memiliki opportunity cost. Artinya setelah peternak memilih opsi memelihara ternak sapi maka ia sudah bersedia menanggung risiko kehilangan peluang lain yang tidak dipilihnya.

Bryan et al. (2011) menyatakan membangun sebuah usaha di bidang pertanian mengandung arti usaha dilihat sebagai kekayaan dimana laba yang diperoleh digunakan untuk merepresentasikan biaya peluang usaha pertanian bersangkutan, dimana laba menunjukkan ukuran return bersih untuk faktor produksi yang telah digunakannya. Berdasarkan konsep opportunity cost ini maka penilaian nilai tambah seperti nilai tabungan sapi yang belum dijual adalah penilaian yang relevan dan realistis. Apalagi sesuai fakta peternak sudah menciptakan nilai tambah pada produk melalui aktivitas bernilai tambahnya. Tabel 5 memperlihatkan reward, value added di atas nilai penghargaan pasar dan persentase nilai tambah di atas biaya kegiatan bernilai tambah peternak sapi. 
Agrinimal, Vol. 8, No. 2, Oktober 2020, Hal. 65-

Tabel 5. Penghargaan Atas Kegiatan Nilai Tambah Peternak

\begin{tabular}{lccccc}
\hline \multirow{2}{*}{ Tahun } & Umur Sapi (th) & $\begin{array}{c}\text { Reward (Nilai } \\
\text { Penghargaan) }\end{array}$ & \multicolumn{2}{c}{ Value Added (VA) } & \multicolumn{2}{c}{$\begin{array}{c}\text { VA/Cptr } \\
(\%)\end{array}$} \\
\cline { 5 - 6 } & & $(\mathrm{Rp})$ & $\mathrm{Rp}$ & $\%$ & 38,89 \\
\cline { 5 - 6 } & 1 & 1.500 .000 & 420.000 & 28,00 & 73,61 \\
Kertama & 2 & 2.500 .000 & 1.060 .000 & 42,40 & 187,78 \\
Ketiga & 3 & 5.180 .000 & 3.380 .000 & 65,25 & 300,28 \\
Total & & 9.180 .000 & 4.860 .000 & 135,65 & \\
\hline
\end{tabular}

Sumber : data lapangan, diolah.

Data pada tabel di atas menunjukkan pada tahun pertama pemeliharaan yaitu sapi berumur hingga 1 tahun, pasar menghargai produk bernilai tambah peternak ini sebesar Rp. 1.500.000-, pada tahun ke-2 produk dihargai sebesar Rp. 2.500.000,-, dan pada tahun ke-3 produk dihargai cash sebesar Rp.5.180.000. Reward yang diberikan pasar terhadap produk nilai tambah peternak adalah cukup besar sehingga hal ini memberikan value added yang lebih besar kepada peternak.

Sesuai data yang ada, nilai tambah yang diterima peternak masing-masing adalah pada pemeliharaan tahun pertama peternak menerima nilai tambah bersih di atas biaya kegiatan bernilai tambah sebesar Rp. 420.000,- atau 28,00\% di atas penghargaan pasar yang diberikan, tahun kedua sebesar Rp. 1.060.000,- atau $42,40 \%$ di atas di atas penghargaan pasar, dan tahun ketiga sebesar Rp. 3.380.000,- atau 65,25\% di atas penghargaan pasar. Dari data ini nilai tambah bersih yang diperoleh peternak terlihat makin meningkat seiring pertam-bahan umur ternak sapi. Secara keseluruhan, terjadi pergerakkan searah antara umur sapi, kegiatan bernilai tambah, dan nilai tambah bersih yang diterima peternak. Hal ini merupakan indikator yang berguna untuk memberikan insentif kepada peternak agar mempertahankan dan meningkatkan produktivitasnya.

Sejalan dengan hasil yang dicapai peternak, Carraher et al. (2008) menyatakan harus tercipta suatu sistem untuk mempertahankan pekerja memberikan produktivitas terbaiknya. Jika dilihat kondisi yang dicapai peternak sapi di Kecamatan Lolong Guba, kondisi pemeliharaan ternak sudah menjadi sistem yang baik yang memberikan balas jasa dan nilai tambah yang layak bagi mereka dan hal ini terjadi secara alami. Sedangkan jika besaran nilai tambah dibandingkan dengan biaya kegiatan bernilai tambah yang telah dibuatkan peternak maka diperoleh persentase masingmasing sebesar tahun pertama $38,89 \%$, tahun kedua $73,61 \%$, dan tahun ketiga $187,78 \%$. Data ini menunjukkan share nilai tambah di atas biaya untuk kegiatan bernilai tambah cukup besar dan makin meningkat. Hal ini pun menunjukkan produktivitas yang diperoleh peternak makin baik dan meningkat.

Tabel 6. Penghargaan Atas Kegiatan Nilai Tambah Pejagal

\begin{tabular}{|c|c|c|c|c|c|}
\hline \multirow[t]{2}{*}{ Periode } & \multirow{2}{*}{$\begin{array}{l}\text { Sapi } \\
\text { (ekor) }\end{array}$} & \multirow{2}{*}{$\begin{array}{l}\text { Reward (Nilai Penghargaan) } \\
\text { (Rp) }\end{array}$} & \multicolumn{2}{|c|}{ Value Added (VA) } & \multirow[t]{2}{*}{ VA/Cpjl (\%) } \\
\hline & & & $\mathrm{Rp}$ & $\%$ & \\
\hline $1 \mathrm{Minggu}$ & 1 & 6.530 .000 & 1.190 .000 & 18,22 & 22,88 \\
\hline 1 Bulan & 4 & 26.120 .000 & 4.760 .000 & 18,22 & 22,88 \\
\hline 1 Tahun & 52 & 339.560 .000 & 61.880 .000 & 18,22 & 22,88 \\
\hline Total & & 372.221 .000 & 67.830 .000 & 54,67 & 66,85 \\
\hline
\end{tabular}

Sumber : data lapangan, diolah.

Tabel 6 menunjukkan reward, value added dan persentase value added di atas biaya kegiatan bernilai tambah pejagal. Data pada tabel menunjukkan bahwa pejagal dalam kegiatan bisnis individunya dan mencari nafkah menerima penghargaan yang cukup besar untuk satu ekor pembelian sapi sebesar Rp. 6.530.000,Reward yang besar ini diperoleh melalui pengeluaran biaya kegiatan bernilai tambah yang juga besar. Kegiatan bernilai tambah pejagal yang membutuhkan biaya cukup besar adalah membeli sapi dari peternak, sedangkan biaya transportasi, retribusi dan RHP hanyalah bagian biaya yang kecil. Karena itu pejagal menerima nilai tambah dari seekor sapi relatif kecil sebesar Rp. 1.190.000,- atau sebesar 18,22 \% di atas nilai penghargaan yang diberikan pasar.

Karena kegiatan bernilai tambah yang dilakukan pejagal membutuhkan periode waktu yang relatif singkat maka pejagal dapat melakukan kegiatan ini secara berulang dalam sebulan bahkan setahun. Amanor-Boadu (2003) menyatakan kegiatan penciptaan 
nilai tambah juga terkait dengan periode waktu. Jika pelaku usaha mampu menciptakan nilai tambah dalam waktu tertentu dan singkat, hal ini dapat terkait kemampuannya untuk menjalankannya sehingga layak menerima imbalan tertentu.

Meskipun pejagal dapat melakukan kegiatan bernilai tambah secara berulang dalam setahun, namun ia hanya menerima persentase nilai tambah di atas reward dengan besaran yang tetap. Hal ini disebabkan karena penggandaan kegiatan bernilai tambah juga menyebabkan penggandaan biaya yang sama. Keunggulan pejagal dalam hal ini dibanding peternak hanyalah mengenai waktu. Karena itu pejagal dapat menikmati penggandaan nilai tambah berdasarkan waktu.

\section{Value Added dan Produktivitas: Peternak vs Pejagal}

Dari data Tabel 5 dan 6 dapat diperbandingkan produktivitas dalam menciptakan nilai tambah antara peternak sapi dan pejagal. Data pada Tabel 5 menunjukkan bahwa peternak memiliki persentase nilai tambah yang meningkat selama 3 tahun pemeliharaan ternak sapi. Indikator ini menunjukkan produktivitas peternak dalam melakukan kegiatan bernilai tambah dihargai oleh pasar dengan nilai cukup besar dan layak. Begitu juga peningkatan nilai tambah yang diterima merupakan imbalan lebih dari produktivitas yang ia ciptakan. Dibandingkan dengan biaya kegiatan bernilai tambah, peternak memiliki produktivitas meningkat. Hal ini menunjukkan produktivitasnya dihargai relatif lebih besar di atas pengorbanannya dalam menyediakan produk (sapi) yang berkualitas bagi pengguna.

Sementara bagi pejagal, persentase nilai tambah yang diterima tetap konstan dan lebih rendah dibanding peternak. Begitu juga perbandingan nilai tambah bersih di atas biaya kegiatan bernilai tambah, juga relatif tetap dan lebih kecil dibanding peternak. Dengan demikian hal ini menunjukkan produktivitas pejagal lebih rendah dibanding peternak terkait penciptaan nilai tambah pada kegiatan pemasaran sapi. Dalam hal ini kegiatan pemeliharaan ternak sapi lebih tinggi menciptakan nilai tambah dibanding kegiatan pemotongan dan penjualan daging sapi di Kecamatan Lolong Guba Kabupaten Buru. Keunggulan bagi pejagal hanyalah terletak pada periode waktu menciptakan nilai tambah.

\section{SIMPULAN DAN REKOMENDASI}

Dari hasil dan pembahasan di atas, dapat ditarik kesimpulan :

1. Peternak sapi potong di Kecamatan Lolong Guba memelihara sapi dalam skala kecil dan dijadikan tabungan keluarga. Pejagal sebagai pelaku usaha individu pemotongan sapi menjual daging ke konsumen akhir.
2. Identifikasi biaya peternak mencakup pemberian hijauan dan pemeliharaan serta penggembalaan ternak, didekati dengan pengukuran implisit sesuai kondisi riil peternak. Pengeluaran biaya pejagal dilakukan mengikuti kondisi riil di lapangan.

3. Kegiatan bernilai tambah peternak mencakup menggembalakan ternak dan menggemukan sapi. Kegiatan bernilai tambah pejagal mencakup membeli dan memotong sapi serta menjual daging.

4. Reward yang diberikan pasar terhadap kegiatan nilai tambah peternak cukup besar dan makin meningkat sesuai jasa mereka membangun kegiatan tersebut. Reward yang diterima pejagal juga cukup besar, namun dengan biaya yang juga cukup besar dari kegiatan bernilai tambah dan mendistribusikan ternak dari peternak ke pasar konsumen daging.

5. Nilai tambah yang diterima peternak sapi relatif tinggi dan meningkat dibanding pejagal yang tetap konstan baik dari besaran nilai maupun persentase.

6. Produktivitas peternak sapi lebih tinggi dibanding pejagal dalam hal menciptakan nila tambah. Peternak lebih unggul dalam pemeliharaan, sedangkan pejagal lebih unggul dalam hal waktu.

Saran yang diberikan berdasarkan hasil penelitian bahwa peternak sapi perlu mempertahankan produktivitasnya agar memiliki posisi tawar yang kuat dalam menetapkan harga jual sapi. Pejagal perlu mempertahankan kegiatannya membeli sapi dan menjual daging ke pasar.

\section{DAFTAR PUSTAKA}

Al-Awawdeh, H. A., S. A. K. Al-Sakini. 2018. The Impact of Economic Value Added, Market Value Added and Traditional Accounting Measures on Shareholders' Value: Evidence from Jordanian Commercial Banks. International Journal of Economics and Finance. $10(10)$ : 40-51. DOI:10.5539/ijef.v10n10p40.

Amanor-Boadu, V. 2003. A Conversation about ValueAdded Agriculture. Value-Added Business Development Program Department of Agricultural Economics. Kansas State University.

Aschea, F., S. C. Kumbhakarb, \& R. Tvetera. 2007. Testing Cost vs Profit Function. Applied Economics Letters. 14: 715-718. DOI: https://doi.org/10.1080/13504850600592655.

[BPS] Badan Pusat Statistik Kabupaten Buru. 2019. Kabupaten Buru Dalam Angka Tahun 2019. Namlea: Badan Pusat Statistik Kabupaten Buru. 
Bryan, B. A., D. King, \& J. R. Ward. 2011. Modelling and Mapping Agricultural Opportunity Costs to Guide Landscape Planning for Natural Resource Management. Ecological Indicators. 11(1): 199-208.

Carraher, S. M., M. R. Buckley, \& S. C. Carraher. 2008. Research Challenges in Sustainable Strategic Management: Change and Sustainable. International Journal Sustainable Strategic Management. 1(1): 1-14.

Hall, J. H. 2013. Toward Improved Use of Value Creation Measures In Financial DecisionMaking. The Journal of Applied Business Research, Vol. 29 (4): pp. 1175-1188. DOI https://doi.org/10.19030/jabr.v29i4.7924.

Lu, R., \& R. Dudensing. 2015. What Do We Mean by Value-Added Agriculture?. Choices. 30(316): 18.

Prasetyo, E., S. Sunarso, P. B. Santosa, \& E. Rianto. 2012. The Influence of Agribusiness Subsystem on Beef Cattle Fattening Farm's Profit in Central Java. Journal of the Indonesian Tropical Animal Agriculture. $\quad 32(2):$ 121-126. DOI: https://doi.org/10.14710/jitaa.37.2.121126.
Puspitaningtyas, Z., A. Toha, \& A. Prakoso. 2018. Understanding the Concept of Profit as An Economic Information Instrument: Disclosure of Semantic Meanings. Accounting and Financial Control. , Vol. 1(1), pp. 27-36. DOI: http://dx.doi.org/10.21511/afc.02(1).2018.03.

Qureshi, M. I., K. Zaman, \& I. A. Shah. 2010. Relationship Between Rewards and Employee's Performance in the Cement Industry in Pakistan. Journal of International Academic Research. 10(2): 19-29. DOI: 10.4236/ti.2013.43019.

Salvatore, D. 2005. Managerial Economics. Ekonomi Manajerial dalam Perekonomian Global. Edisi Kelima. Jakarta: Penerbit Salemba Empat.

Satka, E. 2019. The Impact of Remuneration on Employee Performance in The Trading Company. Human Resource Management Journal. 10(3): 46-62.

Widarti, Subiyanto, \& J. Pramajaya. 2018. The Effect of Profit Management On Company Performance. International Journal of Academic Research in Economics and Management Sciences. 7 (4): 44-63. 